\title{
A Cross-Country Perspective on Professional Oversight, Education Standards and Countries' Perceived Level of Corruption
}

\author{
Albrecht, Chad \\ Malagueño, Ricardo \\ Holland, Daniel \\ Sanders, Matt
}

\begin{abstract}
:
Purpose - This study explores the potential relationship between the existence of a professional oversight body and certain country-specific education regulations in auditing and the country's perceived level of corruption.

Method - Drawing on data from the International Federation of Accountants (IFAC) database, we used univariate (Mann-Whitney $\mathrm{U}$ ) and multivariate analysis techniques to test the difference between countries perceived level of corruption based on whether they have or have not developed professional oversight bodies and licensing regulations.

Findings - Results suggest that countries that have established an audit profession oversight body are, indeed, perceived to be less corrupt. Similarly, countries that require practical experience, academic study, and a licensing examination in order to practice auditing are perceived to be less corrupt. On the other hand, the analysis shows that requiring auditors to fulfil continuing education requirements is not significantly related to corruption. Overall, higher aggregate audit competency standards are associated with lower levels of perceived corruption.
\end{abstract}

Research Implications - The study provides important insights for policy-makers, business leaders, education and the audit profession as a whole. Future research directions are also suggested.

Originality/Value - This paper provides some of the first empirical support for the relationship between corruption and the use of oversight bodies and licensing regulations in professional auditing at a country level.

Key Words: Auditing Education Standards, Professional Oversight Body, Financial Crime, Corruption, International Federation of Accountants. 


\section{Introduction}

This study explores the potential relationship between audit education, audit profession oversight bodies and a country's perceived level of corruption. In recent years, as a result of large-scale scandals in organizations throughout the world, management scholars (Mele and Rosanas, 2005; Hooker, 2009; Albrecht and Albrecht, 2009; Burke, Tomlinson, and Cooper; 2011), investment circles (Pujas, 2003), and regulator communities (Farber, 2005) have had a renewed and increased focus on the topic of business ethics and corruption from a cross cultural perspective.

Research on corruption has demonstrated that institutions such as an audit profession oversight body are an important deterrent to corruption (Lederman et al., 2005). Given that many instances of corruption reported in the press have to do with financial fraud and a lack of internal control over financial assets, it follows that understanding the relationship between certain country-specific audit regulations and corruption would be beneficial in helping countries fight corruption and, in the process, encourage the creation of more efficient audit regulations.

This research uses data from 87 countries collected by the International Federation of Accountants (IFAC) to explore the relationship between the existence of an audit profession oversight body and corruption, the relationship between requirements to obtain an audit license and corruption, and the relationship between requirements to retain an audit license and corruption. Further, this research develops an aggregate measure of audit education, which we refer to as the Index of Audit Education Standards (IAES). Using this index, we examine the relationship between audit education standards, presence of oversight body and corruption while controlling for a country's level of economic freedom and rule of law.

Results from the univariate analyses suggest that countries that have established audit profession oversight bodies are perceived to be less corrupt. Similarly, countries that require 
practical experience, academic study, and a licensing examination in order to receive an audit license are perceived to be less corrupt. However, the analysis shows that requiring auditors to fulfil continuing education requirements, after an initial license has been granted, does not appear to be associated with a lower level of perceived corruption. Results from the multivariate analysis provide support for a significant relationship between the index of audit education standards and corruption.

\section{Corruption and Auditing}

The definition of corruption involves illegal practices that are often associated with illegal cash payments, misallocation of assets, and other inappropriate economically driven transactions (Husted, 1999; Treisman, 2000). Researchers have also suggested that corruption includes financial statement fraud and other similar scandals (Albrecht, et al., 2007). Corruption can involve both public and private settings and can occur in profit and not-forprofit organizations as well as government. In this paper, corruption is defined as the abuse of entrusted power for personal gain.

Research has suggested that there are many mitigating and intervening factors that help explain the relationship between various attributes of a country and corruption. For example research by Treisman (2000) suggests that a country's level of Protestantism, history of British rule, and use of a federal system of governance are negatively correlated with corruption. Similarly, DiRienzo and colleagues (2007) provide evidence to suggest that the accessibility of information within a country is negatively associated with corruption. Other scholars have suggested that inequality of income distribution and government size are mitigating factors of corruption (Husted, 1999). Finally, researchers have suggested that economic freedom (Henderson, 1999), competition (Ades and Di Tella, 1999), human 
development, judicial quality, credit ratings, and the accessibility of newspapers are all mitigating factors of corruption (Galtung, 1997).

The effect that corruption has on countries throughout the world is devastating. For example, scholars have suggested that corruption negatively affects the level of GDP per capita, investment activity, international trade and price stability (Bardhan, 1997). Research has also suggested that corruption distorts the allocation of resources and even discourages the creation of new firms (DeSoto, 1989; Jackson et al., 2010). As a result, corrupt practices raise the real and hidden cost of doing international business, which in turn, negatively affects consumers. Mauro (1995) and Burki and Perry (1998) claim that corruption reduces economic growth by decreasing private investment. Corruption also limits development, as measured by per capita income, and decreases literacy (Kaufman and Kraay, 2002). Some scholars have provided evidence to support the notion that corruption reduces revenue generated through taxation, contributing to the inability of some governments to function properly (Tanzi, 1998). Finally, corruption has been credited with eroding trust in the political system and reducing interpersonal trust in society (Seligson, 2002). While there are many different views on corruption, it is generally acknowledged that the level of corruption in a country reflects the degree to which a society is functional (Steiner, 1999).

Recent studies suggest that political institutions may play an important role in fighting corruption. Political institutions such as democracies, parliamentary systems, political stability and freedom of press have all been associated with lower levels of corruption (Lederman et al., 2005). Since institutions shape the rules of interaction in society, institutions have a direct effect on the incidence of corruption within society. As a result, an effective auditing profession - as an institution (Richardson, 1987) - should directly affect a country`s level of corruption. 
In the international setting, in order to curb corruption, various oversight bodies are in charge of setting auditing and accounting standards that favour transparency. For example, the International Auditing and Assurance Standards Board (IAASB) issues the International Standards on Auditing (ISA). Similarly, the International Accounting Standards Board (IASB) is responsible for setting the International Financial Reporting Standards (IFRS). In the United States, for example, institutions such as the American Institute of Certified Public Accountants (AICPA), the Public Company Accounting Oversight Board (PCAOB), the Securities and Exchange Commission (SEC) and the United States Congress have implemented standards and passed laws such as the Foreign Corrupt Practices Act (FCPA) and the Sarbanes-Oxley Act to deter corruption. The Foreign Corrupt Practices Act prohibits United States listed companies from making bribes in foreign countries and requires them to have internal controls in place to prevent bribes from occurring. Failure to have sufficient controls in place, as evidenced by a bribe, can result in large fines for United States companies and can even result in the company's chief executive officer being imprisoned. Section 404 of the Sarbanes-Oxley Act of 2002 requires management of every United States listed company to assess the adequacy of its internal controls and requires the company's external auditor to independently opine on the adequacy of those controls.

Various theoretical contributions have suggested a link between corruption and auditing. For example, research by Alam (1995) suggests that managerial and accounting skills are possibly correlated to corruption. Shleifer and Vishny (1993) argue that a first step in reducing corruption should be to create an effective accounting and audit profession to prevent theft from government. Finally, Sun (1999) suggests that good accounting regulations in China have already served to lower corruption by uncovering obvious violations and deterring future violations. Since corruption is detrimental to growth in areas with weak rule of law and low government effectiveness (Meon and Sekkat, 2005), corruption is especially 
widespread in countries that lack transparency and have weak or non-existent operations, processes, and laws (LaPalombara, 1994).

While the literature on corruption has addressed many aspects of the economy, there has been little or no empirical research that builds a direct relationship between audit education, oversight boards, regulatory institutions and perceived corruption. This research attempts to build such a link by examining the relationship between certain country-specific audit profession regulations and corruption.

\section{Auditing Processes}

Most researchers today view accounting, including the role of auditing, as an important element of economic reality, rather than a reflection of it. They have provided a view that auditing actually enhances the visibility and transparency of an economy (Becker and Neuheuser, 1975; Burchell et al., 1980). Financial statement auditing has been the primary service provided by auditors and accountants for most of the last 100 years (Knechel, 2001). While auditing standards and technology have become increasingly complex, the basic focus of the audit has not changed - to provide an opinion about the fairness of periodic financial reports. The AICPA, in its Codification of Auditing Standards, has stated that:

"The objective of the ordinary audit of financial statements by the independent auditor is the expression of an opinion on the fairness with which they present... a financial position, results of operations and its cash flows in conformity with generally accepted accounting principles" (AICPA Codification of Auditing Standards, AU Section 110.01, 1972).

However, unfortunately, even in countries with an advanced auditing profession, such as that of the United States, corruption still exists. For example, in the years 2001 and 2002, 
the United States experienced several major frauds, including both Enron and WorldCom. These major frauds and other types of corruption (Tyco, Aldelphia and others) led to increased regulation within the United States, including the passing of the Sarbanes-Oxley Act which created a quasi-governmental accounting oversight body called the Public Company Accounting Oversight Board. Various other countries have adopted similar legislation and organized similar oversight bodies.

The basic purpose of an audit profession oversight body, like the Public Company Accounting Oversight Board, is to oversee the regulation and practice of the auditing profession within a country. The audit profession oversight body does this by monitoring the quality of the audit function in relation to economically significant entities and ensuring independent oversight of the regulation of the audit profession. Although, in most countries, the audit profession oversight body differs slightly in scope and regulation, the purpose of an audit profession oversight body is to have an independent body to oversee the audit profession and to ensure the quality of audits.

In addition to the existence of an audit profession oversight body, the IFAC has recommended that regulations requiring audit education and practical experience be established within each country. The purpose of such regulation is to produce competent professional auditors capable of making a positive contribution to society (International Federation of Accountants, 2003a). International education recommendations for auditors infer that education and practical experience for professional auditors should provide a foundation of knowledge, skills, and values that enable them to learn and adapt to change throughout their professional lives (International Federation of Accountants, 2003b).

\section{Hypothesis Development}


Logic would suggest that establishing audit profession oversight bodies and requiring various forms of auditor education are important deterrents to corruption. Audit education helps ensure that auditors have a knowledge base as well as various competencies (International Federation of Accountants, 2003b). Such competencies help make auditors more vigilant and aware of possible corruption. In turn, perpetrators, when audited by competent auditors, will perceive less opportunity to engage in corrupt practices. Along this same line of reasoning, an audit profession oversight body ensures that the audit profession is overseen and monitored. When the audit profession is overseen and monitored by an independent body, it is much less likely to engage in activities that may compromise an audit, creating less opportunity for perpetrators to engage in corruption.

The need for audit profession oversight bodies to be established in countries throughout the world has been a recurring topic among regulators in recent years. It has been suggested that auditors should be subject to oversight that acts and is seen to act in the public interest (International Organization of Securities Commission, 2002). This independent oversight should be formed to exercise comprehensive oversight over activities that affect the public interest—particularly the establishment of auditing, ethics, and education standards for auditors (International Federation of Accountants, 2006).

In the United Kingdom, for example, the Financial Reporting Council established a professional oversight board in order to build investor, market and public confidence in the financial and governance stewardship of listed and other entities. This is accomplished through the creation of an audit profession oversight body that provides independent oversight of the regulation of the auditing profession by the recognized supervisory and qualifying bodies, monitors the quality of the auditing function in relation to economically significant entities, and oversees the regulation of the auditing profession by professional accountancy bodies (Financial Reporting Council, 2006). 
An audit profession oversight body should generally include the following: (1) a mechanism to ensure that auditors are qualified and competent before being licensed to perform audits and that they maintain professional competence, (2) a mechanism to require that auditors are independent of the entities they audit, both in fact and in appearance, (independence-in-fact is generally understood to mean an unbiased and objective viewpoint when performing audit tests, evaluating results, and issuing audit reports, (Kornish and Levine, 2004)), (3) a mechanism for a body, acting in the public interest, to oversee the quality of auditing, independence, and ethical standards, and (4) a mechanism to require auditors to be subject to a body that is independent of the audit profession (Diplock, 2005).

An audit profession oversight body should act in the public interest, and have an appropriate membership, an adequate charter of responsibilities and power, and adequate funding so that it is not under the control of the auditing profession. The body should establish a process for performing regular reviews of audit procedures and practices of firms that audit the financial statements of listed public companies. The body should be able to stipulate remedial measures for problems as well as initiate disciplinary proceedings and sanctions on auditors and audit firms where appropriate (International Organization of Securities Commissions, 2002).

Major regulatory organizations such as the IFAC and the International Organization of Securities Commissions have recommended that an audit profession oversight body be established in every country. It is logical to assume that those countries with a body that provides independent oversight of the regulation of auditing, monitors the quality of the auditing function in relation to economically significant entities, and oversees the regulation of the audit profession would be more adept at inhibiting corruption through independent audits. It follows that such countries would be perceived to be less corrupt than countries that 
have not established a body to perform these functions. To empirically evaluate this proposition, the following hypothesis is formulated:

\section{H1: Countries that have audit profession oversight bodies are perceived to be less corrupt than countries that have no audit profession oversight bodies.}

The International Organization of Securities Commission (2002) states that one of the basic mechanisms that the audit profession oversight body ensures is that professional auditors are qualified and competent before being licensed to perform audits. The audit profession oversight body also ensures that auditors maintain professional competence. While the hypothesis above simply proposes whether or not an audit profession oversight body has been established within a country, the next hypotheses deal directly with (1) the requirements to obtain an auditing license within a given country and (2) the requirements to retain an auditing license once the license has initially been granted to individuals. The next hypotheses will rely heavily on the international education standards that have been developed by the IFAC. The purpose of these standards is to help guide and set education and training standards for auditors throughout the world.

Researchers have suggested that a lack of professional education is one of the problems contributing to ethical and intellectual failures among accounting practitioners including auditors (Gray et al., 1994). The content of professional audit education should provide a background of accounting, finance and related knowledge; organizational and business knowledge; and information technology knowledge and competences (International Federation of Accountants, 2003b). The study of audit education should be long enough and intensive enough to permit candidates to gain the professional knowledge required for professional competence. The requirement that academic study be necessary in order for 
individuals to obtain an auditing license should increase the confidence of stakeholders of the auditing community or outside observers that audits will be competently performed. Thus,

\section{H2: Countries that require any level of academic study (formal or informal) in order to} obtain an auditing license are perceived to be less corrupt than countries which do not require any level of academic study to obtain an auditing license.

International accounting education standards promulgated by the IFAC Executive Education Committee (International Federation of Accountants, 2003c) recommend that practical experience in accounting is considered necessary before individuals may be able to present themselves to the public as professional auditors. The requirements for practical experience may vary from one country to another. It has been argued that practical experience enhances an individual's understanding of organizations and fosters the acquisition of specific technical know-how (Ashton, 1991). Additionally, experience helps individuals relate auditing work to other functions and activities and encourages individuals to become more aware of the environment in which services are provided, assists in the developing of professional values, ethics, and attitudes in practical and real-life situations, and enables individuals to have an opportunity to work at progressive levels of responsibility (Messier Jr., 1983). Such experience should be perceived as a valuable asset for professional auditors resulting in a higher level of auditing competence. Therefore,

H3: Countries that require practical experience in order to obtain an auditing license are perceived to be less corrupt than countries that do not require practical experience in order to obtain an auditing license. 
International accounting standards recommend that countries have in place assessment procedures to ensure that auditors and other professionals are appropriately qualified. It is recommended that an assessment of capabilities and competence be performed (International Federation of Accountants, 2003d). Assuring that audit professionals are competent and capable means that these individuals have the capabilities and competencies expected of them by employers, clients, and the public. Furthermore, qualified auditors have the ability to protect the public interest by providing fair financial information. By so doing, these professionals provide credibility to the audit and accounting professions (International Federation of Accountants, 2006). Requiring a licensing exam for auditors is an important assessment procedure to ensure that auditors are appropriately qualified. It would be expected that countries that have put in place assessment procedures, such as an auditing licensing exam requirement, would engender perceptions of requiring at least a minimum level of aptitude in thwarting corruption. Therefore, the following hypothesis is tested:

\section{H4: Countries that require a licensing exam in order to obtain an auditing license are perceived to be less corrupt than countries that do not require a licensing exam in order to obtain an auditing license.}

The IFAC International Education Standard \#7 recommends that a continuing professional development requirement be an essential part of a professional auditor's continued ability to perform well (International Federation of Accountants, 2004). This is expected because rules and regulations often change from year to year and auditors should be knowledgeable about such changes in order to meet the needs of the public. Continuing professional development is considered to be relevant, verifiable, and have measurable learning activities and outcomes. The purpose of these learning activities and outcomes is to 
enable auditors to perform competently within their professional environments (International Federation of Accountants, 2006). Standards further recommend that auditors continue to develop and maintain the competencies that are demanded by their professional roles as well as the users of their services. As a result, those countries that require auditors to have continued professional development should be perceived to be less corrupt. Thus,

H5: Countries that require auditors to have continuing professional development (CPD) in order to retain their auditing licenses are perceived to be less corrupt than countries that do not require auditors to have continuing professional development.

Hypotheses 1 through 5 examine the relationship between country-specific characteristics of the audit profession and the perceived corruption of a country; however, these hypotheses do not provide sufficient evidence to establish a unified effect of audit education standards on corruption. Therefore, in the next hypothesis, we evaluate the entire, combined effect of audit education on corruption. This hypothesis is formalized as follows:

H6: Countries that require higher levels of education standards for the audit profession are perceived to be less corrupt than countries that require lower levels of education standards for the audit profession.

\section{Data and Research Design}

Sample and Variables 
To obtain the data needed for this research, we relied on the IFAC database. Specifically, we retrieved data from 87 surveys that were reported in the "Assessment of the Regulatory and Standard-Setting Framework" section of the International Federation of Accountants website. The surveys provided information about the country of origin's statutory framework, audit standards, ethics, education, public sector accounting standards, private sector accounting standards, and quality assurance processes. These surveys were completed by representatives from the various IFAC member bodies in various countries throughout the world. The respondents who completed these surveys were professionals who had practiced auditing within the IFAC member's country of origin. They were also professionals who, as deemed by the IFAC member, are capable of accurately reporting auditing regulation for their respective country. This assessment has provided financial, accounting, and auditing information that was previously unavailable for the majority of countries throughout the world.

Our particular interest in the IFAC survey focused on questions 78 and 79 , in which respondents identified the presence of oversight bodies, and the requirements for obtaining and retaining an auditing license within each country. At the time that the assessment was pulled, data from 87 countries were available for use in the analysis. In order to help the reader better understand which countries were included in the study, Table I provides a descriptive analysis of the countries that completed the survey. This analysis first describes the countries that require an audit profession oversight body. The analysis then shows the countries that require academic study, practical experience, a licensing exam and continuing professional development in order to receive and retain an auditing license within each country. Finally, the table provides information on education quality, requirements for years of professional experience and requirements for continuing professional development. Based 
upon the information in the analysis, we construct a composite score to better understand the level of audit education standards within each country.

\section{Insert TABLE I about Here}

The measurement for corruption was taken from the 2006 Transparency International Corruption Perceptions Index (CPI) (Transparency International, 2006). The CPI has been suggested to be the most comprehensive quantitative indicator of cross-country corruption available (DiRienzo et al., 2007). A study by Lancaster and Montinola (1997) suggested that, while no index or measure of corruption is perfect, the CPI is robust. The CPI ranks countries in terms of the degree to which corruption is perceived to exist among public officials, politicians and the private sector. The CPI is a composite index, drawing on corruptionrelated data from numerous surveys. The index gives a composite score between one and ten, with ten being those countries with the least amount of perceived corruption and one being those countries with the highest amount of perceived corruption.

The difficulty in assessing the actual level of corruption within a country has been recognized for many years (Johnston, 2000; Jain, 2001; Lederman et al., 2005). Unfortunately, hard empirical data on corruption is typically biased and lacks validity (Lambsdorff, 2007). Data such as prosecutions or court cases, for example, do not reflect actual levels of corruption. Rather, they are evidence of the level of which prosecutors, courts, and media expose corruption. As a result, since actual levels of corruption are unobservable (Kurer, 2005), researchers must rely on the perception of corruption as built on the experience and perceptions of those who are most directly confronted with the realities of corruption. The Corruption Perception Index by Transparency International provides such a measure. 


\section{Research Design}

In order to test the hypotheses 1 through 5 , the data that were retrieved from the IFAC database were analysed by performing several Mann-Whitney U tests. The Mann-Whitney U test is a non-parametric hypothesis test for which normal distribution is not required (Bergman et al., 2000). Such tests are performed to determine if there are differences in the perceived corruption of groups of countries who use the hypothesized variables (e.g. oversight bodies, education requirements, etc.) and those countries that do not employ such standards.

Before testing hypothesis 6, we built a composite index using the hypothesized variables from hypotheses 2 - 5. The Index of Audit Education Standards (IAES) corresponds to weighted composite that accounts for the existence of requirements such as, accounting and auditing academic study, professional experience, proficiency exams, and continuing professional development. In order to consider the effect that a country's quality of education may have on the requirements for academic study within a country, we weighted the existence of academic study with Global Competitiveness Report's "Higher Education and Training" measurement (World Economic Forum, 2009). Similarly, instead of only considering the existence or not of a professional experience requirement for individuals to obtain an audit license, the IAES index also weighted the number of years of professional experience each country requires. Table I depicts the total IAES composite and the variables used in its construction. Further, we weighted the continuing professional development (CPD) measure with several characteristics that describe the $\mathrm{CPD}$ requirement in each country. These characteristics include: (a) The categories or items that are required to maintain professional competence through continued professional development within each country, (b) The required hours of continuing professional development within each country, (c) The monitoring of continuing professional development within each country, and (d) The 
monitoring processes of continuing professional development within each country. Appendix A shows the features that were used to weight the continuing professional development measure. Information on years of professional experience and continuing professional development requirements were obtained from the IFAC database Survey - Part 2.

To test hypothesis 6, we regressed the index of IAES and the existence of an oversight body with corruption while controlling for intervening effects. The control variables used in these models includes both economic freedom and rule of law. Economic freedom represents the fundamental right of every human to be in command of his/her own labour and property. Economic freedom is a common control variable when measuring corruption, and previous research has indicated that economic freedom represents a significant effect on corruption (Ades and Di Tella, 1999, Treisman, 2000). Other studies have emphasized the essential role of rule of law for a country's economic development and level of corruption (Nwabuzor, 2005). Efficient rule of law offers a stable structure for economic activity. Failure to enforce property rights and contracts undermines the incentives for agents to participate in productive activities and consequently increases rent-seeking (Mehlum et al., 2006). As a result, we use the rule of law as a second control variable. An overview of all the variables used in the study, including their measures, is reported in Table II below.

\section{Insert TABLE II about Here}

\section{Empirical Results}

Table III below presents the means, medians, standard deviations, and Z statistics for the results of hypotheses 1 through 5 . The results show that the establishment of a professional oversight body is negatively related to perceived corruption $(Z=-4.022, p<$ .01). $\mathrm{H} 1$ is supported. $\mathrm{H} 2$ suggests that a requirement for academic study in order to obtain an 
auditing license will be negatively related to perceived corruption. The results support H2 ( $\mathrm{Z}$ $=-2.057, \mathrm{p}<.05) . \mathrm{H} 3$ is also supported as countries that required practical experience for auditors were perceived to have significantly less corruption $(Z=-2.198, p<.05)$. Countries that required a licensing exam were also perceived to have significantly less corruption $(\mathrm{Z}=-$ 2.745, $\mathrm{p}<.01)$. Thus, H4 was supported. However, H5 was not supported as the relationship between continuing professional development and perceived corruption was not significant $(\mathrm{Z}=-0.280, \mathrm{p}>.10)$.

\section{Insert TABLE III About Here}

Table IV below depicts the descriptive statistics and bivariate correlations among variables that are used to examine hypothesis 6 . Table $\mathrm{V}$ provides the results of the multivariate analysis. The results of these analyses suggest that the index of audit education standards and the existence of an oversight body are significant in explaining corruption $(\mathrm{p}<.05)$.

\section{Insert TABLE IV and TABLE V About Here}

\section{Discussion and Future Research}

The results of this study suggest that countries that have an audit profession oversight body are perceived to be less corrupt than countries that do not have an audit profession oversight body. Results also suggest that countries that require academic study, practical experience, and a licensing exam in order to obtain an auditing license are also perceived to be less corrupt. However, the results indicate that the requirement to have continuing professional development in order for auditors to retain their licenses is not significantly related to a country's perceived level of corruption. It may be that continuing professional 
development programs are devalued for auditors that are active under the assumption that practical experience will trump what might be learned in specific development programs. Or perhaps it is viewed that setting a high bar to earn a license to audit is much more important than the ongoing maintenance of the license with regards to inhibiting corruption.

Further analysis of the data used in this study suggests that the development of the accounting profession within a country typically goes through two stages of development. The first stage of development typically includes a combination of several certifying requirements for auditors. Such certifying requirements may include academic study, professional experience, licensing exams, and/or continuing professional development. Once these basic requirements are met, accounting professions within a country will then typically implement an audit profession oversight body. For example, fourteen countries from Africa a region of world considered to have many "lesser developed" countries (United Nations, 2007 ) - only had two countries with an audit profession oversight body. On the other hand, of the eight countries from Western Europe - a region of the world considered to be composed of "developed countries" - five countries had established an audit profession oversight body.

The correlation between regulatory bodies and procedures and developed countries is not new (Brownbridge and Kirkpatrick, 2002) and has been considered to be a deterrent against corruption and other forms of inappropriate behaviour for some time. Because of the relationship between regulatory bodies and procedures and developed countries, developing nations are at an increased risk for corruption. As such, many scholars have suggested that many developing countries throughout Asia were particularly vulnerable during the Asian financial crisis (Fischer 1998; Haggard, 2000). Furthermore, scholars have even suggested that the recent world financial crisis of 2008 and 2009 is the result of a lack of regulation and oversight in both developed and underdeveloped countries (Appelbaum and Cho, 2009; Hamilton, 2009). For this reason, financial experts from over 20 countries have proposed that 
all countries, especially developing countries, need more regulation and oversight of fiscal institutions including better accounting and auditing standards (Group of Twenty Industrialized and Developing Economies, 2009).

In many industrial and developed countries, the audit profession is subject to discipline in addition to those imposed by oversight institutions. Such discipline includes civil litigation and similar consequences that result from unprofessional behaviour, including corruption, by auditors. The threat of such sanctions on the audit profession creates an enormous pressure for auditors to behave ethically. On the other hand, in some of the least developed countries rule of law is so low that the possibility of these sanctions is minimal or non-existent.

The recommendation to have an audit profession oversight body has not been stressed as an important step in the development of an audit profession within a country until the last few years. As has been stated, having an audit profession oversight body is usually one of the last regulatory developments in maturing economies. In analysing those countries that have established an audit profession oversight body, it is interesting to note that, in general, their auditing profession and business regulatory environments are quite advanced. As a group, they are perceived to be significantly less corrupt than those countries that have not established such bodies.

While this study reviews different regulation for auditors from around the world, the international audit profession is converging to some generally accepted audit regulations. The most representative example of this convergence is found in the European Union. Directives EU 1984 and 2006 established legislation for a common framework for the competence of auditors. This directive sets minimum requirements including a university degree, practical experience, and a written examination in order to be certified as an auditor. In addition to these minimum criteria, European Union members are allowed to apply additional requirements at the country level, as each country sees fit. As a result, most auditors 
throughout the European Union have received practical experience and passed an audit examination before becoming a licensed auditor.

As the auditing profession continues to move towards international auditing standards, this research may provide a foundation for additional research to better understand the most effective education model for auditors. In fact, in recent years a debate has emerged between the chartered accountant model of accounting education that stresses more practical experience and less formal education and the US-type academic model that stresses more formal education and less practical experience. Future research could address which type of accounting education and regulation has the greatest impact on the deterrence of corruption. Such a study may provide information to determine if professional auditor training should be focused on formal education requirements or practical experience.

In a sense, this research is only an exploratory study into the relationship between country-specific audit practices and corruption. As a result, the analysis presented in this paper does not examine the quality of the oversight body in place nor the varying degrees of auditor requirements. For example, in this study we hypothesized the presence of an oversight body to be positively associated with lower levels of corruption. Nevertheless, the presence of oversight does not equal judicious oversight. It might be the case in some countries that an abuse of power through oversight bodies could be the source of much of the corruption. Future research could aim to investigate the attributes of particular oversight bodies across countries. Furthermore, this study is incomplete and calls for further research as it does not examine the varying degrees of auditor requirements. For instance, the difference between the types of exams and the specific training (i.e. continuing professional development - CPD) that are required by each country in order to gain and retain auditing license is not measured. In this study we only examine whether or not a country does or does not have a licensing exam and CPD in order to obtain and retain an auditing license. In this 
vein, a potential explanation for the lack of relationship found between CPD and corruption (H5) could be associated with the type of training required instead of the simple presence/amount of CPD offered by each country. An area for future research may be to investigate this and the other descriptive and comparative auditor requirements for different countries. Case studies on auditor regulation and audit profession oversight bodies are especially needed.

Finally, there may be some interesting cross-cultural research opportunities. For example, it is interesting to note that while some areas of the world - such as ex-communist countries (e.g. Eastern Bloc States) - have high levels of regulation in place, these countries are still perceived to have high levels of corruption. This is consistent with previous research that suggests that regulation, in and of itself, does not lower corruption (Cheung, 1996). Various cultures view human behaviour through different lenses which results in profoundly different behavioural norms. Hooker (2009) argued that there are two broad classifications of norms - rule-based norms evolve from the fundamental respect for rules and relationshipbased norms are regulated by a respect for authority figures and connections with one's network. It would be naïve to expect that a one-size-fits-all approach to regulation would be equally effective in rules-based and relationship-based cultures. Future research could shed light on the types of regulation that are most effective for any particular cultural norm. It would also be very interesting to see more research on the relationship between the general cultural dimensions of countries and the types of corruption that are common, the use of regulatory standards, the types of regulatory standards, and the effectiveness of regulatory standards. For example, Sanyal \& Guvenli (2009) found that different cultural dimensions (e.g. power distance) helped to explain the difference in countries' propensity to engage in bribery but less so than the general economic condition of the countries. In a similar manner, 
research could be extended to examine how cultural dimensions might be related to corruption in accounting and related general oversight practices.

\section{Conclusion}

The goal of this paper has been to further examine the relationship between countryspecific audit regulation and perceived corruption. Since a higher perceived level of corruption curtails foreign investment and hurts gross domestic product, implementing audit education and regulations that are significantly associated with less perceived corruption may be a vital step in the fight against corruption.

While the results reported in this study test many international auditing recommendations, specifically those of the International Federation of Accountants, additional research is warranted to better understand the effects that international audit recommendations have upon countries ' economies, societies, and the audit profession as a whole.

In conclusion, this paper contributes to the literature on the relationship between corruption and the audit profession in several ways. First, the study examines a relationship in which little empirical research has been developed - bringing new insight to the international audit community. Second, the research presented in this paper provides an in-depth investigation into the recent and, for the most part, unexplored IFAC database on the regulatory and standard-setting framework for the audit profession. Finally, this study has suggested a significant positive relationship between the use of oversight bodies and licensing requirements and a lower perception of corruption, providing empirical evidence of the importance of such measures. This study has been a first step only and additional research is needed to better understand the relationship between the audit profession and corruption. 


\section{References}

Ades, A. and Di Tella, R. (1999), "Rates, Competition, and Corruption", American Economic Review, Vol. 89 No. 4, pp. 982 - 93.

Alam, M. (1995), “A Theory of Limits on Corruption and Some Applications”, Kyklos, Vol. 48 , pp. $419-35$

Albrecht, C. O. and Albrecht, C. C. (2009), "International Ethics, Fraud, and Corruption: A Cross-Cultural Perspective", Cross Cultural Management, Vol. 16 No. 3, Introduction to the Special Issue.

Albrecht, C.O., Dolan, S. and Albrecht, C. C. (2007), "Financial fraud: The How and Why", European Business Forum, Vol. 29 Summer, pp. 35 - 39.

American Institute of Certified Public Accountants (AICPA). (1972), “Codification of Auditing Standards and Procedures", Statement on Auditing Standards No. 1 [AU 110] (AICPA, New York).

Appelbaum, B. and Cho, D. (2009), "Geithner to Propose Vast Expansion of U.S. Oversight of Financial System", Washington Post, March 26, 2009, Available at: http://www.washingtonpost.com/wpdyn/content/article/2009/03/25/AR2009032502311.h $\operatorname{tml}$

Ashton, A. H. (1991), “Experience and Error Frequency Knowledge as Potential Determinants of Audit Expertise”, Accounting Review, Vol. 66 No. 2, pp. 218 - 39.

Bardhan, P. (1997), "Corruption and Development: A Review of Issues”, Journal of Economic Literature, Vol. 35 No. 3, pp. 1320 - 46.

Becker, S. W. and Neuhauser, D. (1975), The Efficient-Organization, Elsevier, New York, NY. 
Brownbridge M. and Kirkpatrick, C. (2002), "Policy Symposium: Financial Regulation and Supervision in Developing Countries", Development Policy Review, Vol. 20 No. 3, pp. $243-45$.

Burchell, S., Clubb, C., Hopwood, A., Hughes, J. and Nahapiet, J., (1980), “The Roles of Accounting in Organizations and Society", Accounting, Organizations, and Society, Vol. 5 No. 1 , pp. $5-27$.

Burke, R. J., Tomlinson, E. D. and Cooper, C. L. (2011), Crime and Corruption in Organizations, Gower Publishing, England.

Burki, S. and Perry, G. (1998), Beyond the Washington Consensus: Institutions Matter, World Bank, Washington DC.

Cheung, S. (1996), “A Simplistic General Equilibrium Theory of Corruption”, Contemporary Economic Policy, Vol. 15 No. 3, pp. 1 - 5.

DeSoto, H. (1989), The Other Path: The Invisible Revolution in the Third World, Harper, New York.

Diplock, J. (2005), “Importance of Audit Quality and Auditing Standards New Zealand and International Perspectives", New Zealand Institute of Chartered Accountants Wellington Seminar, 11 November, 2005.

DiRienzo, C. E., Das, J., Cort, K. T., and Burbridge, J. (2007), “Corruption and the Role of Information”, Journal of International Business Studies, Vol 38 No. 2, pp. 320 - 32.

Farber, D. B. (2005), "Restoring Trust After Fraud: Does Corporate Governance Matter?" The Accounting Review, Vol. 80 No. 2, pp. $539-61$.

Financial Reporting Council (FRC). (2006), The Professional Oversight Board, Available at http://www.frc.org.uk/index.cfm, Accessed: August 1, 2011.

Fischer, S. (1998), “The Asian Crisis: A View from the IMF”, Journal of International Financial Management and Accounting, Vol. 9 No. 2, pp. 167 - 76. 
Galtung, F. (1997), “The Social and Economic Implications of Corruption”, Transparency International (TI) Report 1997, Berlin, Germany.

Global Competitiveness Report. (2009), World Economic Forum, Geneva, Switzerland.

Gray R., Bebbington, J., McPhail, K. (1994), “Teaching Ethics in Accounting and the Ethics of Accounting Teaching: Educating for Immorality and a Possible Case for Social and Environmental Accounting Education”, Accounting Education, Vol. 3 No. 1, pp. 51-75.

Group of Twenty Industrialized and Developing Economies. (2009), “Text of the Communique of the G-20”. Accessed on August 1, 2011 at: http://www.timesonline.co.uk/tol/news/politics/G20/article6023679.ece

Haggard, S. (2000), The Political Economy of the Asian Financial Crisis, Institute for International Economics, Washington D.C.

Hamilton, J. (2009), "Former SEC Chair Breeden Urges Merger of SEC, CFTC, and PCAOB”, CCH Financial Crisis News Center, Accessed on August 1, 2010 at: http://www.financialcrisisupdate.com/.

Henderson, D. R. (1999), "Power Corrupts - Editorial Comment", The Wall Street Journal, April 19, 1999.

Hooker, J. (2009), “Corruption from a Cross-Cultural Perspective”, Cross Cultural Management: An International Journal, Vol. 16 No. 3, pp. 251 - 67.

Husted, B.W. (1999), “Wealth, Culture, and Corruption”, Journal of International Business Studies, Vol. 30 No. 2, pp. $339-60$.

International Federation of Accountants (IFAC). (2003a), Introduction to International Education Standards, IFAC, New York, NY.

International Federation of Accountants (IFAC). (2003b), International Education Standards \#2, IFAC, New York, NY. 
International Federation of Accountants (IFAC). (2003c), International Education Standards \#5, IFAC, New York, NY.

International Federation of Accountants (IFAC). (2003d). International Education Standards \#6, IFAC, New York, NY.

International Federation of Accountants (IFAC). (2004). International Education Standards \#7, IFAC, New York, NY.

International Federation of Accountants (IFAC). (2006). Descriptions of IFAC, Available at: http: //www.iasplus.com/ifac/ifac.htm, Accessed: January 1, 2011.

International Organization of Securities Commission (IOSCO). (2002), "Principles for Auditor Oversight", A Statement of the Technical Committee of the International Organization of Securities Commissions (IOSCO, Madrid).

Jackson, K., Holland, D. V., Albrecht, C., Woolstenhulme, D. R. (2010) “Fraud Isn't Just For Big Business: Understanding the Drivers, Consequences, and Prevention of Fraud in Small Business.” Journal of International Management Studies, Vol. 5 No. 1, pp. 160 164.

Jain, A. K. (2001), “Corruption: A Review”, Journal of Economic Surveys, Vol. 15 No. 1, pp. $71-121$

Johnston, M. (2000), “Measuring Corruption: Numbers versus Knowledge versus Understanding”, In: A.K. Jain, Editor, The Political Economy of Corruption, Routledge, New York, NY.

Kaufmann, D. and Kraay, A. (2002), "Growth Without Governance”, Economia, Vol. 3 No. 1, pp. $169-230$.

Knechel, R. W. (2001), Auditing: Assurance and Risk, Thompson South-Western, Cincinnati, Ohio. 
Kornish, L. J. and Levine, C. B. (2004), "Discipline with Common Agency: The Case of Audit and Nonaudit Services", The Accounting Review, Vol. 79. No. 1, pp. 173 - 200.

Kurer, O. (2005), "Corruption: An Alternative Approach to its Definition and Measurement", Political Studies, Vol. 53 No. 1, pp. 222 - 239.

Lambsdorff, J.G. (2007), The New Institutional Economics of Corruption and Reform: Theory, Policy, and Evidence, Cambridge University Press, Cambridge, United Kingdom.

Lancaster, T. D. and Montinola, G. R. (1997), “Toward a Methodology for the Comparative Study of Political Corruption”, Crime, Law and Social Change, Vol. 27 No. 3 - 4, pp. $85-206$.

LaPalombara, J. (1994), "Structural and Institutional Aspects of Corruption”, Social Research Vol. 61 No. 2, pp. $325-350$.

Lederman, D., Loayza, N. V. and Soares, R. R. (2005), “Accountability and Corruption: Political Institutions Matter", Economics and Politics, Vol. 17 No. 1, 1- 35. Mauro, P. (1995), “Corruption and Growth”, Quarterly Journal of Economics, Vol. 110 No. 3, pp. $681-712$.

Mehlum et al., H. Mehlum, K. Moene and Torvik, R. (2006), "Institutions and the previous termresourcenext term curse", The Economic Journal, 116, pp. 1-20.

Mele, D. and Rosanas, J. (2005), "Ethics in Accounting and Accountability: Editorial Introduction”, Journal of Business Ethics, Vol. 57 No. 1, 1 - 3.

Meon, P. and Sekkat, K. (2005), “Does Corruption Grease or Sand the Wheels of Growth?”, Public Choice, Vol. 122 No. 1, pp. 69 - 97.

Messier Jr., W. F. (1983), “The Effect of Experience and Firm Type on Materiality/Disclosure Judgements", Journal of Accounting Research, Vol. 21 No. 2, pp. $611-618$. 
Nwabuzor, A.(2005), "Corruption and Development: New Initiatives in Economic Openness and Strengthened Rule of Law”, Journal of Business Ethics, Vol. 59 No. 1, pp. 121- 138.

Pujas, V. (2003), “The European Anti-Fraud Office (OLAF): A European Policy to Fight Against Economic and Financial Fraud?", Journal of European Public Policy, Vol. 10 No. 5, pp. $778-97$.

Richardson, A. J. (1987), “Accounting as a Legitimating Institution”, Accounting, Organizations and Society, Vol. 12 No. 6, pp. 344 - 351.

Sanyal, R. and Guvenli, T. (2009), "The Propensity to Bribe in International Business: The Relevance of Cultural Variables", Cross Cultural Management: An International Journal, Vol. 16 No. 3, pp. 287 - 300.

Seligson, M. (2002), "'The Impact of Corruption on Regime Legitimacy: A Comparative Study of Four Latin American Countries," The Journal of Politics, Vol. 64 No. 2, pp. $408-433$.

Shleifer, A. and Vishny, R. (1993), “Corruption”, The Quarterly Journal of Economics, Vol. 108 No. 3, pp. $599-617$.

Steiner, A. (1999), “Accountability And The Environment The Need For A Joint Initiative Of Public, Private And Civil Society Sectors", The 9th International Anti-Corruption Conference, October 10 - 15, 1999, Durban, South Africa.

Sun, Y. (1999), "Reform, State, and Corruption: Is Corruption Less Destructive in China than in Russia?", Comparative Politics, Vol. 32 No. 1, pp. 1 - 20.

Tanzi, V. (1998), “Corruption Around the World: Causes, Consequences, Scope and Cures”, IMF Staff Papers, Vol. 45 No. 4, pp. 559 - 94.

Transparency International. (2006), Corruption Perceptions Index 2005, Available at http://www.transparency.org/policy_research/surveys_indices/cpi/2005, Accessed: August 1, 2011. 
Treisman, D. (2000), “The Causes of Corruption: A Cross-National Study”, Journal of Public Economics, Vol. 76 No. 3, pp. 399 - 457.

United Nations. (2007), Principle 10, The UN Global Compact, available at: www.unglobalcompact.org, Accessed: August 1, 2011. 
TABLE I

Audit Requirements per Country

\begin{tabular}{|c|c|c|c|c|c|c|c|c|c|}
\hline Country & $\begin{array}{l}\text { Oversight } \\
\text { Body }\end{array}$ & $\begin{array}{c}\text { Academic } \\
\text { Studies } \\
\text { Required } \\
\end{array}$ & $\begin{array}{c}\text { Professional } \\
\text { Experience } \\
\text { Required } \\
\end{array}$ & $\begin{array}{c}\text { License } \\
\text { Exam }\end{array}$ & $\begin{array}{c}\text { Cont.Prof. } \\
\text { Devel. } \\
\text { Required }\end{array}$ & $\begin{array}{c}\text { Education } \\
\text { Quality }\end{array}$ & $\begin{array}{c}\text { Professional } \\
\text { Experience }\end{array}$ & $\begin{array}{l}\text { Cont. Prof. } \\
\text { Devel. }\end{array}$ & IAES $^{\dagger}$ \\
\hline & & & $1=y e s, 0=$ no & & & Rating & Years & $\begin{array}{c}C P D \\
\text { requirement }\end{array}$ & \\
\hline Albania & 1 & 1 & 1 & 1 & 1 & 3.3 & 3 & 7 & 0.62 \\
\hline Argentina & 0 & 1 & 0 & 0 & 0 & 2.9 & - & - & 0.12 \\
\hline Armenia & 0 & 0 & 0 & 1 & 0 & 3.0 & - & - & 0.25 \\
\hline Australia & 1 & 1 & 1 & 0 & 1 & 5.5 & 3 & 11 & 0.54 \\
\hline Austria & 0 & 1 & 1 & 1 & 1 & 5.2 & 3 & 8 & 0.72 \\
\hline Azerbaijan & 0 & 1 & 1 & 1 & 1 & 3.3 & 3 & 8 & 0.64 \\
\hline Bangladesh & 0 & 0 & 1 & 1 & 1 & 2.9 & 2 & 6 & 0.44 \\
\hline Barbados & 0 & 0 & 1 & 0 & 1 & 5.1 & - & 7 & 0.13 \\
\hline Belgium & 1 & 1 & 1 & 1 & 1 & 6.0 & 3 & 10 & 0.79 \\
\hline Botswana & 0 & 1 & 1 & 1 & 1 & 3.8 & 3 & 8 & 0.66 \\
\hline Brazil & 0 & 1 & 0 & 1 & 1 & 2.7 & - & 8 & 0.51 \\
\hline Bulgaria & 0 & 1 & 1 & 1 & 1 & 3.3 & 4 & 9 & 0.70 \\
\hline Chile & 0 & 1 & 0 & 0 & 0 & 3.2 & - & - & 0.13 \\
\hline China & 1 & 0 & 1 & 1 & 1 & 3.8 & 2 & 7 & 0.46 \\
\hline Cyprus & 0 & 0 & 1 & 1 & 0 & 5.4 & 3 & - & 0.36 \\
\hline Czech Re. & 0 & 1 & 1 & 1 & 1 & 4.7 & 3 & 10 & 0.74 \\
\hline Denmark & 1 & 1 & 1 & 1 & 0 & 5.8 & 3 & - & 0.59 \\
\hline Dominican & 0 & 1 & 0 & 0 & 0 & 2.2 & - & - & 0.09 \\
\hline Estonia & 0 & 1 & 1 & 1 & 1 & 4.5 & 3 & 9 & 0.71 \\
\hline Fiji & 0 & 0 & 0 & 0 & 0 & & - & - & - \\
\hline Finland & 1 & 1 & 1 & 1 & 0 & 6.2 & 3 & - & 0.61 \\
\hline France & 1 & 1 & 1 & 1 & 1 & 5.0 & 3 & 11 & 0.77 \\
\hline Germany & 1 & 1 & 1 & 0 & 0 & 4.9 & 2 & - & 0.27 \\
\hline Ghana & 0 & 1 & 1 & 0 & 1 & 3.4 & 4 & 8 & 0.43 \\
\hline Greece & 1 & 1 & 0 & 0 & 0 & 3.3 & - & - & 0.13 \\
\hline Guatemala & 1 & 1 & 0 & 0 & 0 & 2.6 & - & - & 0.10 \\
\hline Guyana & 0 & 1 & 1 & 0 & 1 & 3.6 & 3 & 7 & 0.39 \\
\hline Hong Kong & 1 & 0 & 1 & 1 & 0 & 4.9 & 3 & - & 0.36 \\
\hline Hungary & 0 & 1 & 1 & 1 & 1 & 3.2 & 3 & 11 & 0.70 \\
\hline Iceland & 0 & 1 & 1 & 1 & 1 & 5.9 & 3 & 8 & 0.75 \\
\hline India & 0 & 1 & 1 & 0 & 1 & 4.3 & 3 & 8 & 0.43 \\
\hline Indonesia & 0 & 1 & 1 & 0 & 1 & 4.2 & - & 10 & 0.36 \\
\hline Iran & 0 & 0 & 1 & 0 & 1 & & 6 & 10 & 0.41 \\
\hline Ireland & 1 & 1 & 1 & 1 & 1 & 5.6 & 3 & 12 & 0.81 \\
\hline Israel & 1 & 1 & 1 & 1 & 0 & 4.0 & 2 & - & 0.48 \\
\hline Italy & 1 & 1 & 1 & 1 & 1 & 3.2 & 3 & 10 & 0.68 \\
\hline Ivory Coast & 0 & 0 & 0 & 0 & 0 & 2.9 & - & - & - \\
\hline Jamaica & 1 & 1 & 1 & 0 & 1 & 3.0 & 3 & 9 & 0.40 \\
\hline Japan & 1 & 0 & 1 & 1 & 1 & 4.5 & 3 & 11 & 0.57 \\
\hline Jordan & 0 & 1 & 1 & 1 & 1 & 4.6 & 3 & - & 0.54 \\
\hline Kazakhstan & 0 & 1 & 1 & 0 & 1 & 3.6 & 3 & 11 & 0.46 \\
\hline Kenya & 0 & 1 & 1 & 0 & 1 & 4.4 & 3 & 9 & 0.46 \\
\hline Korea & 1 & 1 & 1 & 1 & 0 & 4.6 & 2 & - & 0.51 \\
\hline Kuwait & 0 & 1 & 1 & 1 & 0 & 3.1 & 5 & - & 0.55 \\
\hline Kyrgyzstan & 0 & 1 & 1 & 1 & 1 & 3.4 & 1 & 8 & 0.58 \\
\hline Latvia & 0 & 1 & 1 & 0 & 1 & 3.7 & 3 & 8 & 0.41 \\
\hline Lesotho & 0 & 1 & 1 & 0 & 1 & 3.3 & 3 & 10 & 0.43 \\
\hline Lithuania & 1 & 1 & 1 & 1 & 1 & 3.7 & 3 & 8 & 0.66 \\
\hline Madagascar & 0 & 0 & 0 & 1 & 0 & 2.9 & - & - & 0.25 \\
\hline Malawi & 0 & 0 & 1 & 1 & 1 & 3.6 & 3 & 10 & 0.55 \\
\hline Malaysia & 0 & 1 & 1 & 0 & 1 & 5.0 & 3 & 9 & 0.48 \\
\hline Malta & 1 & 1 & 1 & 0 & 1 & 4.9 & 3 & 9 & 0.48 \\
\hline Mexico & 0 & 1 & 0 & 0 & 0 & 2.8 & 3 & - & 0.11 \\
\hline Moldova & 0 & 1 & 1 & 1 & 0 & 3.2 & 5 & - & 0.56 \\
\hline Mongolia & 1 & 1 & 1 & 0 & 1 & 2.5 & 2 & 6 & 0.29 \\
\hline Morocco & 0 & 0 & 0 & 1 & 1 & 3.0 & - & 9 & 0.42 \\
\hline
\end{tabular}




\begin{tabular}{|c|c|c|c|c|c|c|c|c|c|}
\hline Country & $\begin{array}{l}\text { Oversight } \\
\text { Body }\end{array}$ & $\begin{array}{c}\text { Academic } \\
\text { Studies } \\
\text { Required }\end{array}$ & $\begin{array}{c}\text { Professional } \\
\text { Experience } \\
\text { Required }\end{array}$ & $\begin{array}{c}\text { License } \\
\text { Exam }\end{array}$ & $\begin{array}{c}\text { Cont. } \\
\text { Prof. } \\
\text { Devel. } \\
\text { Required }\end{array}$ & $\begin{array}{c}\text { Education } \\
\text { Quality }\end{array}$ & $\begin{array}{l}\text { Professional } \\
\text { Experience }\end{array}$ & $\begin{array}{c}\text { Cont. } \\
\text { Prof. } \\
\text { Devel. }\end{array}$ & IAES \\
\hline Namibia & 0 & 0 & 0 & 0 & 0 & 2.7 & - & - & - \\
\hline Nepal & 0 & 1 & 1 & 0 & 0 & 3.0 & 3 & 0 & 0.23 \\
\hline Netherlands & 1 & 1 & 1 & 0 & 1 & 5.3 & 3 & 8 & 0.47 \\
\hline New Zealand & 0 & 0 & 1 & 0 & 1 & 4.9 & 3 & 9 & 0.28 \\
\hline Nigeria & 0 & 0 & 1 & 0 & 1 & 3.7 & 2.5 & 8 & 0.24 \\
\hline Norway & 1 & 1 & 1 & 0 & 1 & 5.4 & 3 & 7 & 0.46 \\
\hline Pakistan & 0 & 1 & 1 & 0 & 0 & 2.9 & 3 & - & 0.22 \\
\hline Panama & 0 & 1 & 0 & 0 & 0 & 2.8 & - & 0 & 0.11 \\
\hline Poland & 0 & 1 & 1 & 1 & 1 & 3.8 & 3 & - & 0.51 \\
\hline Portugal & 1 & 1 & 1 & 1 & 0 & 3.5 & 3 & - & 0.50 \\
\hline Romania & 0 & 1 & 1 & 1 & 1 & 3.6 & 3 & 11 & 0.71 \\
\hline Russia & 1 & 1 & 1 & 1 & 1 & 4.3 & 3 & 11 & 0.74 \\
\hline Saudi Arabia & 0 & 1 & 1 & 1 & 1 & 3.6 & 3 & 13 & 0.75 \\
\hline Singapore & 1 & 1 & 1 & 0 & 1 & 6.2 & 3 & 9 & 0.53 \\
\hline Slovakia & 0 & 1 & 1 & 0 & 1 & 3.4 & 5 & 9 & 0.49 \\
\hline Slovenia & 1 & 1 & 1 & 1 & 1 & 4.4 & 5 & 8 & 0.76 \\
\hline South Africa & 1 & 0 & 0 & 0 & 0 & 2.8 & - & - & - \\
\hline Spain & 0 & 1 & 1 & 1 & 1 & 3.8 & 3 & 7 & 0.64 \\
\hline Sri Lanka & 1 & 1 & 1 & 0 & 1 & 4.1 & 4 & - & 0.31 \\
\hline Sweden & 1 & 1 & 1 & 1 & 0 & 5.3 & 3 & - & 0.57 \\
\hline Switzerland & 1 & 1 & 1 & 1 & 1 & 6.0 & 7 & 13 & 0.99 \\
\hline Tanzania & 0 & 0 & 1 & 0 & 1 & 3.1 & 3 & 10 & 0.30 \\
\hline Thailand & 0 & 1 & 1 & 1 & 1 & 3.8 & 3 & - & 0.51 \\
\hline Trinidad & 0 & 0 & 1 & 0 & 1 & 4.1 & 3 & 8 & 0.26 \\
\hline Turkey & 0 & 1 & 1 & 1 & 0 & 3.4 & 2 & - & 0.46 \\
\hline Ukraine & 0 & 0 & 1 & 0 & 1 & 4.2 & 2 & 8 & 0.23 \\
\hline United K. & 1 & 1 & 1 & 1 & 1 & 4.6 & 3 & 10 & 0.73 \\
\hline United States ${ }^{\mathrm{a}}$ & 1 & 1 & 1 & 1 & 1 & 5.0 & 1 & 13 & 0.74 \\
\hline Uzbekistan & 1 & 0 & 0 & 0 & 1 & & 3 & 9 & 0.17 \\
\hline Zambia & 0 & 0 & 1 & 0 & 1 & 3.6 & 3 & 10 & 0.30 \\
\hline Zimbabwe & 0 & 1 & 1 & 0 & 1 & 4.1 & 3 & 10 & 0.46 \\
\hline
\end{tabular}

Note: Descriptive Analysis of the Number of - "Yes" Answers to Each of the Questions in the Assessment Regarding the Existence of an Audit Profession Oversight Body as well as the Existence of Requirements for Academic Study, Practical Experience, Licensing Exam, and Continuing Professional Development in Order to Receive and Retain an Audit License (1 $=$ yes, $0=$ no). Further, this table describe the variables (i.e. Education Quality, Years of Professional Experience, and CPD requirement) used to weight the Index of Audit Education Standard (IAES) (see Table II for a description of variables).

${ }^{\dagger} I A E S=($ Academic Studies Required $*$ Education Quality/Max(Education Quality $\left.) * 0.25\right)+($ Professional Experience Required*Years Professional Experience/Max(Years Professional experience)*0.25)+(Continuing Prof. Devel. Required $* C P D$ Requir./Max (CPD Requir. $) * 0.25)+($ Lic. Exam $* 0.25)$

a "The experience requirement varies from zero (in 2 states) to 2 years (in 20 states). The balance of the states require one year of experience. Most states require a component of the experience to be in audit and assurance services." (IFAC Survey, Assessment of the Regulatory and Standard-Setting Framework, American Institute of Certified Public Accountants - 2006) 


\section{TABLE II}

Description of the dependent and independent variables

\begin{tabular}{|c|c|}
\hline Variable & Description \\
\hline Oversight Body & $\begin{array}{l}\text { Dummy variable that equals } 1 \text { if the country have established an audit professional oversight } \\
\text { body; } 0 \text { otherwise. From the IFAC survey - Assessment of the Regulatory and Standard-Setting } \\
\text { Framework. }\end{array}$ \\
\hline Academic Study & $\begin{array}{l}\text { Dummy variable that equals } 1 \text { if the country requires academic study to professional to obtain an } \\
\text { audit license; } 0 \text { otherwise. From the IFAC survey -Assessment of the Regulatory and } \\
\text { Standard-Setting Framework. }\end{array}$ \\
\hline $\begin{array}{l}\text { Professional } \\
\text { Experience }\end{array}$ & $\begin{array}{l}\text { Dummy variable that equals } 1 \text { if the country requires practical experience to professional to } \\
\text { obtain an audit license; } 0 \text { otherwise. From the IFAC survey - Assessment of the Regulatory and } \\
\text { Standard-Setting Framework. }\end{array}$ \\
\hline License Exam & $\begin{array}{l}\text { Dummy variable that equals } 1 \text { if the country requires license exam to professional to obtain an } \\
\text { audit license; } 0 \text { otherwise. From the IFAC survey -Assessment of the Regulatory and } \\
\text { Standard-Setting Framework. }\end{array}$ \\
\hline $\begin{array}{l}\text { Continuing } \\
\text { Professional } \\
\text { Development }\end{array}$ & $\begin{array}{l}\text { Dummy variable that equals } 1 \text { if the country requires continuing professional development to } \\
\text { auditor to retain an audit license; } 0 \text { otherwise. From the IFAC survey - Assessment of the } \\
\text { Regulatory and Standard-Setting Framework. }\end{array}$ \\
\hline
\end{tabular}

Corruption Perceptions $\quad$ Refers to CPI 2006 from the Transparency International.

Index (CPI)

Education Quality

Quality of the higher education and training as presented by The Global Competitiveness Report 2008-2009. Greater scores represent greater higher education system.

Years Professional

Experience

From the IFAC survey -Part 1 and Part 2, refers to the number of years required for each country for a professional to become a licensed auditor.

CPD Requirements

Summation of CPD requirements as in the IFAC survey - Response to the IFAC Part 2, Statements of Membership Obligations Self-Assessment Questionnaire. See Appendix A for detailed list of questions and items taken into consideration.

Index of Audit Education Standards (IEAS)

The IAES corresponds to a weighted composite that takes into account the requirements of academic studies, professional experience, proficiency exam, and continuing professional development. The existence of academic studies is weighted by quality of the education system. The requirement for professional experience was weighted by the number of years required for each country for a professional to become a licensed auditor. Continuing professional development was weighted by summation of several characteristics required by each country (see Appendix A). The index is weighted such that the minimum score is 0 and the maximum is 1 , being 0 equals to no requirement for audit license to be granted and 1 equal to the higher level of requirements.

Economic Freedom Economic freedom represents the fundamental right of every human to be in command of his/her own labour and property. The Index of Economic Freedom refers to the period of 2006 and was gathered from The Heritage Foundation at www.heritage.org.

Rule of Law

Measures the perceptions of the extent to which agents have confidence in and abide by the rules of society, including the quality of contract enforcement, property rights, police, and courts. In this paper we use data provided by the World Bank for the period of 2006. 


\section{TABLE III}

Descriptive statistics and Mann-Whitney U test

\begin{tabular}{|c|c|c|c|c|c|c|c|}
\hline Hypothesis & Requirement & Group & $\mathrm{N}$ & Mean & Median & Std.Dev. & $\mathrm{Z}$ \\
\hline $\mathrm{H} 1$ & $\begin{array}{l}\text { Establishment of Audit } \\
\text { Professional Oversight Body }\end{array}$ & $\begin{array}{l}\text { No } \\
\text { Yes }\end{array}$ & $\begin{array}{l}54 \\
33\end{array}$ & $\begin{array}{l}3.94 \\
6.26\end{array}$ & $\begin{array}{l}3.25 \\
6.60\end{array}$ & $\begin{array}{l}1.85 \\
2.45\end{array}$ & $-4.022 * *$ \\
\hline $\mathrm{H} 2$ & $\begin{array}{l}\text { Academic Study Requirement } \\
\text { to Obtain an Audit License }\end{array}$ & $\begin{array}{l}\text { No } \\
\text { Yes }\end{array}$ & $\begin{array}{l}22 \\
65\end{array}$ & $\begin{array}{l}4.01 \\
5.10\end{array}$ & $\begin{array}{l}3.15 \\
4.70\end{array}$ & $\begin{array}{l}2.17 \\
2.39\end{array}$ & $-2.057 *$ \\
\hline $\mathrm{H} 3$ & $\begin{array}{l}\text { Practical Experience } \\
\text { Requirement to Obtain an } \\
\text { Audit License }\end{array}$ & $\begin{array}{l}\text { No } \\
\text { Yes }\end{array}$ & $\begin{array}{l}16 \\
71\end{array}$ & $\begin{array}{l}3.49 \\
5.12\end{array}$ & $\begin{array}{l}3.15 \\
4.80\end{array}$ & $\begin{array}{l}1.25 \\
2.47\end{array}$ & $-2.198 *$ \\
\hline $\mathrm{H} 4$ & $\begin{array}{l}\text { Licensing Exam Requirement } \\
\text { to Obtain an Audit License }\end{array}$ & $\begin{array}{l}\text { No } \\
\text { Yes }\end{array}$ & $\begin{array}{l}42 \\
45\end{array}$ & $\begin{array}{l}4.20 \\
5.40\end{array}$ & $\begin{array}{l}3.20 \\
5.10\end{array}$ & $\begin{array}{l}2.28 \\
2.34\end{array}$ & $-2.745^{* *}$ \\
\hline H5 & $\begin{array}{l}\text { Continuing Professional } \\
\text { Development Requirement to } \\
\text { Retain an Audit License }\end{array}$ & $\begin{array}{l}\text { No } \\
\text { Yes }\end{array}$ & $\begin{array}{l}27 \\
60\end{array}$ & $\begin{array}{l}4.87 \\
4.80\end{array}$ & $\begin{array}{l}4.10 \\
3.70\end{array}$ & $\begin{array}{l}2.37 \\
2.40\end{array}$ & -0.280 \\
\hline
\end{tabular}

$\mathrm{CPI}=$ Dependent variable. $* \mathrm{p}<.05 ; * * \mathrm{p}<.01$ (two-tailed tests).

\section{TABLE IV}

Descriptive statistics and bivariate correlation

\begin{tabular}{|c|c|c|c|c|c|c|c|c|c|c|}
\hline & \multicolumn{6}{|c|}{ Descriptive Statistics } & \multicolumn{4}{|c|}{ Bivariate Correlation $^{a}$} \\
\hline & Mean & $\underline{\text { Std. }}$ & $\underline{\text { Min }}$ & $\underline{\operatorname{Max}}$ & Skew. & $\underline{\text { Kurtosis }}$ & $\underline{(1)}$ & (2) & (3) & $(4)$ \\
\hline (1) CPI & 4.82 & 2.37 & 2.00 & 10.00 & 0.70 & -0.86 & & & & \\
\hline (2) IAES & 0.45 & 0.22 & 0.00 & 0.99 & -0.19 & -0.56 & $0.403 * *$ & & & \\
\hline (3) Oversight & 0.38 & 0.48 & 0.00 & 1.00 & 0.50 & -1.78 & $0.477 * *$ & $0.234 *$ & & \\
\hline (4) Ec. Free. & 63.89 & 9.79 & 33.54 & 88.61 & 0.15 & 0.47 & $0.813 * *$ & $0.294 * *$ & $0.373^{* *}$ & \\
\hline (5) $\log$ (Rule of Law) & 1.67 & 0.32 & 0.28 & 2.00 & -1.92 & 4.65 & $0.727 * *$ & $0.334 * *$ & $0.281 * *$ & $0.716 * *$ \\
\hline
\end{tabular}

${ }^{\text {a }}$ Pearson correlation reported. $\mathrm{n}=87 ; * \mathrm{p}<.05 ; * * \mathrm{p}<.01$ (two-tailed tests). 


\section{TABLE V}

The following table examines the relationship between the corruption perception index and the index of audit education standards (IAES) and oversight body, while including control variables.

\begin{tabular}{|c|c|c|c|c|}
\hline & \multicolumn{2}{|c|}{ (1) } & \multicolumn{2}{|c|}{ (2) } \\
\hline & Coef. & t-stat. & Coef. & t-stat. \\
\hline Intercept & $2.588 * *$ & 5.300 & $-7.374 * *$ & -8.160 \\
\hline IAES & $3.289 * *$ & 3.327 & $1.279^{*}$ & 2.019 \\
\hline Oversight & $1.971 * *$ & 4.360 & $0.877 * *$ & 2.990 \\
\hline Econ.Freedom & & & $0.127 * *$ & 6.367 \\
\hline Rule of Law & & & $1.897 * *$ & 3.268 \\
\hline $\mathrm{R}^{2}(\operatorname{adj})$ & 0.301 & & 0.737 & \\
\hline F-stat & $19.510 * *$ & & $61.33^{* *}$ & \\
\hline Max_VIF & 1.058 & & 2.199 & \\
\hline $\mathrm{N}$ & 87 & & 87 & \\
\hline
\end{tabular}

Note: Dependent variable $=$ CPI 2006. $* \mathrm{p}<.05 ; * * \mathrm{p}<.01$ (two-tailed tests). 


\section{Appendix A}

CPD Requirements Assessed by IFAC Survey Part 2

(Cursive characters explain the value given to the answer used to compose the CPD requirement weight).

2.14.2. Which membership categories are required to maintain professional competence through continuous professional development? Select all the answer options that are appropriate.

1) All our qualified members $(0=$ non selected, $4=$ selected $)$

2) Qualified members who perform audits of listed entities (Only if first item different from 4, $0=$ non selected, $1=$ selected)

3) Qualified members who perform audits of entities other than listed entities (as above)

4) Qualified members who provide services (other than audit) to the public (as above)

5) Qualified members who are employed in business (as above)

2.14.3.1. Type of CPD Requirement - Which of the following answer options describes the way the continuous professional development is structured? Select all the answer options that are appropriate. $(0=$ non selected, $1=$ selected $)$

1) Members must satisfy a number of hours of continuous professional development a year or over a number of years

2) All members are to satisfy specified content requirements (e.g. Specified courses or knowledge content)

3) Members working in specialist areas or areas of high risk to the public are to satisfy specified content requirements (e.g. Specified courses or knowledge content)

2.14.3.3. Hours of Continuous Professional Development - Which one of the following answer options best describes the continuous professional development hours required?

1) Members have to complete a minimum of 120 hours or equivalent learning units of relevant professional development activity over a three-year rolling period. $(0=$ non selected, $1=$ selected $)$

2) Members have to complete a minimum of 20 hours or equivalent learning units in each year $(0=$ selected $)$

2.14.3.8. Monitoring of CPD - Is there a process to monitor whether your members who are qualified as professional accountants meet the continuous professional development requirements?

1) Yes, there is a monitoring process for $\mathrm{CPD}$ requirements $(0=$ non selected, $1=$ selected $)$

2) No, there is no monitoring process for CPD requirements $(0=$ selected $)$

2.14.4.1. Monitoring Process SMO 2 - Which of the following elements does the monitoring process include? Select all the answer options that are appropriate.

1) Professional accountants are required to submit a declaration $(0=$ non selected, $1=$ selected $)$

2) Professional accountants are required to submit evidence $(0=$ non selected, $1=$ selected $)$

3) Our organization audits a sample of professional accountants to check compliance $(0=$ non selected, $1=$ selected $)$

4) Compliance is monitored through firm quality control standards $(0=$ non selected, $1=$ selected $)$

5) Compliance is monitored through a quality assurance review program $(0=$ non selected, $1=$ selected $)$ 